\title{
Monakolina - pomost między prozdrowotną modyfikacją diety a farmakoterapią hipercholesterolemii
}

\author{
Monacolin - bridging therapy between the modification of diet \\ and the pharmacotherapy of dyslipidemia
}

\author{
Beata Wożakowska-Kapłon ${ }^{1,2}$, Paweł Salwa ${ }^{1}$ \\ ${ }^{1}$ I Klinika Kardiologii i Elektroterapii Świętokrzyskiego Centrum Kardiologii \\ ${ }^{2}$ Wydział Lekarski i Nauk o Zdrowiu Uniwersytetu Jana Kochanowskiego w Kielcach
}

\section{Streszczenie}

Choroby układu sercowo-naczyniowego (CVD) są główną przyczyną przedwczesnych zgonów na świecie. Z kolei dyslipidemia to najczęściej występujący, modyfikowalny czynnik ryzyka CVD. Podstawę interwencji służącej normalizacji stężenia cholesterolu stanowi postępowanie niefarmakologiczne obejmujące modyfikację stylu życia, w tym przede wszystkim aktywność fizyczną i odpowiednią dietę. Grupą leków najczęściej stosowaną w leczeniu zaburzeń gospodarki lipidowej są statyny. Pośrednim etapem między postępowaniem niefarmakologicznym a leczeniem statynami może być zastosowanie żywności funkcjonalnej oraz suplementów diety, takich jak monakolina K. Skuteczność monakoliny K zawartej w czerwonym ryżu drożdżowym w obniżaniu stężenia cholesterolu potwierdzono w wielu randomizowanych badaniach klinicznych. Zastosowanie suplementów diety oraz żywności funkcjonalnej jako alternatywy dla leczenia statyną jest uprawnione tylko u pacjentów z niskim bądź umiarkowanym ryzykiem sercowo-naczyniowym, ewentualnie w tej grupie chorych obciążonych wysokim ryzyka sercowo-naczyniowym, u których wyjściowo stężenie cholesterolu frakcji LDL nie przekracza $100 \mathrm{mg} / \mathrm{dl}$.

Słowa kluczowe: dyslipidemia, ryzyko sercowo-naczyniowe, statyny

Folia Cardiologica 2016; 11, 4: 318-326

\section{Wstęp}

Choroby układu sercowo-naczyniowego (CVD, cardiovascular diseases) stanowią główną przyczynę przedwczesnych zgonów na świecie. W krajach europejskich CVD odpowiadają za 52\% zgonów u kobiet oraz 37\% u mężczyzn poniżej 75. roku życia [1]. Dyslipidemia jest najczęściej występującym, modyfikowalnym czynnikiem ryzyka chorób sercowo-naczyniowych.

Zaburzenia lipidowe mogą być efektem interakcji między czynnikami środowiskowymi i genetycznymi lub wynikać z innych schorzeń, na przykład przewlekłej choroby nerek (CKD, chronic kidney disease), zespołu nerczycowego, chorób wątroby, chorób spichrzeniowych, endokrynologicznych. Mogą też być skutkiem stosowania niektórych leków, na przykład glikokortykosteroidów. Wówczas są to dyslipidemie wtórne.

Największe znaczenie przypisuje się podwyższonemu stężeniu frakcji lipoprotein o niskiej gęstości (LDL, low-density lipoprotein), cholesterolu całkowitego (TC, total cholesterol), stężeniu apolipoproteiny B (apoB) u osób charakteryzujących się dużym ryzykiem lub obciążonych

Adres do korespondencji: lek. Paweł Salwa, I Klinika Kardiologii i Elektroterapii, Świętokrzyskie Centrum Kardiologii, ul. Grunwaldzka 45, 
rodzinnie oraz wartości cholesterolu nie-HDL (nie-HDL-C) w przypadku dyslipidemii mieszanej, cukrzycy, zespołu metabolicznego i CKD. Dane naukowe pochodzące z wielu randomizowanych badań klinicznych potwierdzają, że zmniejszenie stężenia LDL oraz TC może zapobiegać rozwojowi CVD, dlatego te parametry stanowią najważniejszy cel leczenia dyslipidemii. Cząsteczki LDL są głównym transporterem cholesterolu w osoczu, a z uwagi na niewielkie rozmiary mają zdolność przenikania przez śródbłonek tętnic, gdzie po związaniu z proteoglikanami, ulegają oksydacyjnej modyfikacji w obecności wolnych rodników tlenowych i w wyniku interakcji z makrofagami inicjują powstawanie blaszki miażdżycowej. Przenikanie lipoprotein jest łatwiejsze w przypadku dysfunkcji śródbłonka naczyniowego, co przyśpiesza tym samym rozwój miażdżycy. Przez śródbłonek przenikają również aterogenne lipoproteiny o pośredniej gęstości (IDL, intermediate density lipoprotein) oraz tak zwane małe gęste LDL obciążone większą ilością apolipoproteiny B (apoB) w stosunku do zawartości cholesterolu w cząsteczce. Ze względu na mniejszą zawartość antyoksydantów są one bardziej podatne na działanie wolnych rodników tlenowych, a ich niewielkie rozmiary znacznie ułatwiają przedostawanie się przez śródbłonek. Lipoproteiny o wysokiej gęstości (HDL, high-density lipoprotein) mają zdolność wiązania cholesterolu znajdującego się w makrofagach ściany tętnicy i po powrocie do światła naczynia transportują cholesterol do wątroby, gdzie jest on metabolizowany. Uważa się, że ta frakcja lipoprotein pełni funkcję ochronną, a zmniejszone stężenie HDL-C uznawane jest za czynnik ryzyka sercowo-naczyniowego.

\section{Typy zaburzeń gospodarki lipidowej}

Wyróżnia się następujące typy zaburzeń gospodarki lipidowej:

- hipercholesterolemia - stężenie LDL-C większe lub równe $115 \mathrm{mg} / \mathrm{dl}$ ( $\geq 3 \mathrm{mmol} / \mathrm{l})$; stężenie TC większe lub równe $190 \mathrm{mg} / \mathrm{dl}$ ( $\geq 5 \mathrm{mmol} / \mathrm{l})$;

- dyslipidemia aterogenna - współwystępowanie podwyższonego stężenia TG większego lub równego $150 \mathrm{mg} / \mathrm{dl}$ (1,7 mmol/l), niskiego stężenia HDL-C $1<40 \mathrm{mg} / \mathrm{dl}$ [1,0 mmol/l] u mężczyzn i $<45 \mathrm{mg} / \mathrm{dl}$ [1,2 mmol/l] u kobiet) oraz obecności nieprawidłowych cząstek LDL, tak zwanych małych gęstych LDL. Stężenie LDL-C może być w tym przypadku prawidłowe lub podwyższone, nosząc wówczas nazwę dyslipidemii mieszanej;

- hipertriglicerydemia - stężenie TG większe lub równe $150 \mathrm{mg} / \mathrm{dl}(\geq 1,7 \mathrm{mmol} / \mathrm{l})[2]$.

\section{Zaburzenia gospodarki lipidowej- najpowszechniejszy czynnik ryzyka schorzeń sercowo-naczyniowych w Polsce}

Częstość występowania dyslipidemii w populacji polskiej oceniono w rejestrze NATPOL 2011 [3]. Badanie zostało przeprowadzone w reprezentatywnej grupie 1168 mężczyzn oraz 1245 kobiet w wieku 18-79 lat. Hipercholesterolemię definiowaną jako stężenie TC $\geq 190 \mathrm{mg} / \mathrm{dl}$ lub terapię statyną rozpoznano u 61,1\% dorosłych Polaków. Częstość występowania zwiększonego stężenia LDL-C ( $\geq 115 \mathrm{mg} / \mathrm{dl}$ ) w całej badanej grupie wynosiła 57,8\% (u 58,3\% mężczyzn i $57,3 \%$ kobiet). Stężenie HDL-C $<40 \mathrm{mg} / \mathrm{dl}$ stwierdzono u 35,2\% mężczyzn, a poniżej $45 \mathrm{mg} / \mathrm{dl}$ - u 22,2\% kobiet, hipertriglicerydemia rozpoznana została u 21,1\% badanych. Wśród osób z hipercholesterolemią aż 58,7\% badanych nie było świadomych występowania zaburzeń lipidowych, a $22 \%$ nie stosowało leczenia pomimo wiedzy na temat dyslipidemii. Jedynie u 10,9\% badanych stosowane leczenie było skuteczne (TC < $190 \mathrm{mg} / \mathrm{dl}$ ).

Przeprowadzenie przesiewowych badań lipidogramu umożliwia odpowiednio wczesne wykrycie zaburzeń profilu lipidowego, zastosowanie odpowiedniego leczenia, a także monitorowanie prowadzonej terapii. Podstawowa ocena profilu lipidowego powinna obejmować ocenę stężenia TC, frakcji LDL, HDL oraz stężenie TG.

\section{Oszacowanie ryzyka sercowo-naczyniowego podstawą wyznaczenia celu terapii dyslipidemii}

Podstawą do rozpoczęcia leczenia, sposobu oraz pilności jej stosowania, a także do wyznaczenia celu terapeutycznego w przypadku rozpoznania dyslipidemii jest ocena ryzyka sercowo-naczyniowego przeprowadzona między innymi za pomocą narzędzi diagnostycznych, takich jak skala SCORE.

Bardzo wysokie ryzyko sercowo-naczyniowe cechuje osoby:

- z udokumentowaną CVD, przebytym zawałem serca, ostrym zespołem wieńcowym, po rewaskularyzacji tętnic wieńcowych, po udarze niedokrwiennym mózgu;

- z cukrzycą typu 2, cukrzycą typu 1 z powikłaniami narządowymi (mikroalbuminuria);

- z przewlekłą chorobą nerek z przesączaniem kłębuszkowym (GFR, glomerular filtration rate) poniżej $60 \mathrm{ml}$ $/ \mathrm{min} / 1,73 \mathrm{~m}^{2}$;

- z ryzykiem sercowo-naczyniowym wyższym lub równym $10 \%$. Wysokie ryzyko sercowo-naczyniowe cechuje osoby:

- u których stwierdza się występowanie jednego silnego czynnika ryzyka (rodzinna hipercholesterolemia, ciężkie nadciśnienie tętnicze);

- z wyliczonym ryzykiem wyższym lub równym 5\% i niższym od $10 \%$.

Umiarkowane ryzyko sercowo-naczyniowe stwierdza się u osób, u których wyliczone na podstawie tabeli SCORE ryzyko zgonu w perspektywie 10 -letniej wynosi $1 \%$ lub więcej i mniej niż 5\%.

0 niskim ryzyku sercowo-naczyniowym mówi się wówczas, gdy wyliczone według SCORE ryzyko nie przekracza $1 \%$. 
Głównym celem postępowania w dyslipidemiach jest zmniejszenie stężenia LDL-C do wartości docelowych [4]. Dowodów na słuszność takiego postępowania dostarczają randomizowane badania kliniczne, w których stężenie LDL-C było wyznacznikiem skuteczności prowadzonego leczenia hipolipemizującego [5-7]. Intensywność prowadzonej terapii powinna zależeć od całkowitego ryzyka CV oraz od wyjściowego stężenia LDL-C. W metaanalizie 26 badań przeprowadzonych łącznie wśród ponad 170 tys. chorych dowiedziono, że obniżenie stężenia LDL-C o 1,0 mmol// $(38,6 \mathrm{mg} / \mathrm{dl})$ powoduje zmniejszenie ryzyka zgonu z powodu CVD o około 22\% [5]. Poprzez ekstrapolację danych z badań klinicznych wyznaczono wartości docelowe stężenia LDL-C dla poszczególnych grup ryzyka CV:

- u osób z bardzo wysokim ryzykiem CV (SCORE $\geq 10 \%$, jawna CVD, cukrzyca typu 2, cukrzyca typu 1 z powikłaniami narządowymi, CKD z GFR < $60 \mathrm{ml} / \mathrm{min} / 1,73 \mathrm{~m}^{2}$ ) celem terapii jest osiągnięcie stężenia LDL-C poniżej $70 \mathrm{mg} / \mathrm{dl}$ (1,8 mmol/l) lub obniżenie LDL o więcej niż $50 \%$ wartości wyjściowej;

- u osób z wysokim ryzykiem sercowo-naczyniowym (SCORE $\geq 5$ i < 10\%) należy dążyć do obniżenia stężenia LDL-C poniżej $100 \mathrm{mg} / \mathrm{dl}$ (2,5 mmol/l);

- u osób z ryzykiem umiarkowanym (SCORE $\geq 1 \mathrm{i}<5 \%$ ) stężenie LDL-C nie powinno przekraczać $115 \mathrm{mg} / \mathrm{dl}$ (3 mmol/l);

- osoby z niskim ryzykiem nie wymagają interwencji. Synteza postępowania w przypadku dyslipidemii została zawarta w II Deklaracji Sopockiej [2]. W dokumencie omówiono wszystkie elementy prawidłowo prowadzonego postępowania terapeutycznego w dyslipidemiach.

\section{Piramida modyfikacji lipidogramu}

Podstawę interwencji mającej na celu normalizację stężenia cholesterolu stanowi postępowanie niefarmakologiczne polegające na modyfikacji stylu życia, obejmującej przede wszystkim aktywność fizyczną i odpowiednią dietę. Istotnymi elementami prozdrowotnej modyfikacji sposobu odżywiania są dostosowanie podaży energii dostarczanej z pożywieniem do indywidualnego zapotrzebowania i redukcja dostarczania energii pochodzącej z nasyconych kwasów tłuszczowych oraz izomerów trans nienasyconych kwasów tłuszczowych. Zwiększenie spożycia jedno- oraz wielonienasyconych kwasów tłuszczowych, a także zmniejszenie zawartości cholesterolu w pożywieniu również stanowią elementy korzystnej zmiany nawyków żywieniowych. Stosowanie żywności funkcjonalnej z uwzględnieniem fitosteroli, fitostanoli oraz wzbogacenie jej o suplementy diety, takie jak monakolina, stanowi kolejny etap postępowania niefarmakologicznego. Postępowanie takie pozwala na redukcję stężenia LDL-C w stosunku do wartości wyjściowej nawet do około 30\%. W sytuacji gdy postępowanie niefarmakologiczne nie stwarza możliwości osiągnięcia docelowej wartości LDL-C oraz u osób obciążonych wysokim i bardzo wysokim ryzykiem sercowo-naczyniowym terapię hipolipemizującą prowadzi się za pomocą statyn. W terapii dyslipidemii, niezależnie od jej przyczyny, statyny odgrywają główną rolę z uwagi na ich bezpośrednie działanie hipolipemizujące dotyczące cholesterolu, zwłaszcza jego frakcji LDL, lecz także ze względu na ich działanie plejotropowe, niezwiązane bezpośrednio ze zmniejszeniem stężenia cholesterolu, takie jak między innymi poprawa funkcji komórek śródbłonka, stabilizacja blaszki miażdżycowej, działanie antyagregacyjne, przeciwzapalne i immunomodulujące. Ideę stopniowanej intensywności postępowania hipolipemizującego przedstawia piramida modyfikacji lipidogramu zaproponowana przez autorów Deklaracji Sopockiej (ryc. 1). Podkreślenia wymaga jednak fakt, że zastosowanie suplementów diety oraz żywności funkcjonalnej jako alternatywy dla leczenia statyną uprawnione jest jedynie u pacjentów z niskim bądź umiarkowanym ryzykiem sercowo-naczyniowym, ewentualnie w tej grupie chorych dużego ryzyka sercowo-naczyniowego, u których wyjściowo stężenie LDL-C nie przekracza 100 mg/dl [8].

Fitosterole i fitostanole to substancje pochodzenia roślinnego o budowie podobnej do cholesterolu konkurujące $z$ cholesterolem o wchłanianie w jelitach. Sterole są wiązane przez umieszczone na powierzchni jelit receptory dla cholesterolu, co powoduje hamowanie wchłaniania cholesterolu i zwiększenie jego wydalania z kałem [9]. Działanie takie dotyczy zarówno cholesterolu dostarczanego z pożywieniem, jak i endogennego, będącego produktem syntezy wątrobowej. Głównym źródłem steroli i stanoli roślinnych są takie produkty jak rośliny strączkowe, oleje roślinne oraz nasiona słonecznika i ziarno sezamowe. Stosując żywność funkcjonalną zawierającą sterole i stanole (2 g/d.), można uzyskać redukcję LDL-C o około 10\% w stosunku do wartości wyjściowych. Redukcja ta stanowi wartość dodaną zarówno w przypadku stosowania diety niskocholesterolowej, jak i statyn. Obecnie na rynku dostępne są także margaryny roślinne wzbogacane w fitosterole i fitostanole.

\section{Monakolina - naturalna statyna w terapii zaburzeń lipidowych}

\section{Statyny - historia odkryć}

W 1973 roku Akira Endo i wsp. wykazali hipolipemizujące działanie mewakoliny - substancji wyizolowanej z grzyba Penicillium citrinum. Substancja ML-236B, nazwana później mewastatyną, wykazywała właściwości zmniejszania stężenia TC i LDL-C w surowicy krwi zwierząt laboratoryjnych i ludzi poprzez hamowanie końcowych szlaków biosyntezy cholesterolu [10]. Pięć lat po tym odkryciu grupa badaczy kierowana przez Alfreda Albertsa uzyskała podczas procesu fermentacji grzyba Aspergillus terreus substancję nazwaną mewinoliną, będącą analogiem mewakoliny [11]. Jednocześnie badania prowadzone przez Endo pozwoliły 


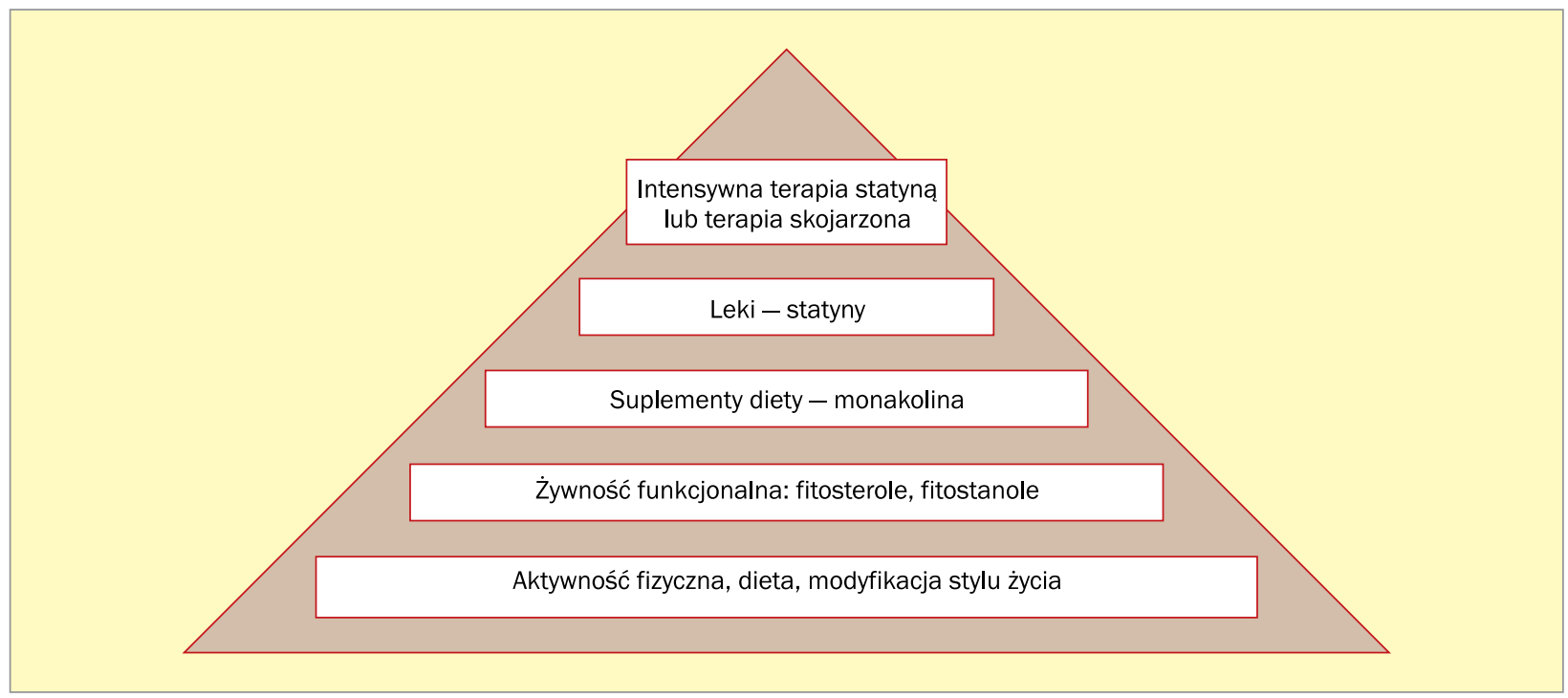

Rycina 1. Piramida modyfikacji lipidogramu (źródło [2])

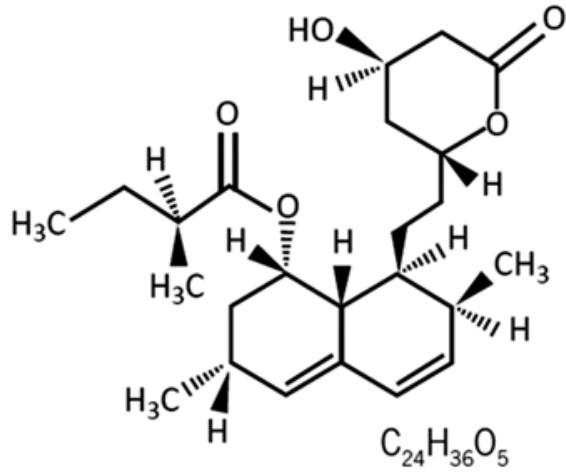

Rycina 2. Budowa chemiczna mewinoliny, monakoliny K i lowastatyny

na izolacje z grzyba Monascus ruber statyny nazwanej monakoliną K. Badania przeprowadzone jeszcze $w$ tym samym roku pozwoliły ustalić, że mewinolina i monakolina to ten sam związek chemiczny nazwany lowastatyną (ryc. 2). Substancja w roku 1980 uzyskała ochronę patentową, a w 1987 jako pierwsza statyna została wprowadzona na rynek farmaceutyczny pod nazwą Mevacor ${ }^{\circledast}$ [12].

Lowastatyna jest prolekiem uzyskującym aktywność in vivo poprzez hydrolizę pierścienia laktonowego do kwasu lowastatynowego. Syntetycznym analogiem lowastatyny jest simwastatyna posiadająca dodatkową grupę metylową. Źródłem lowastatyny jest jadalny grzyb boczniak ostrygowaty. Naturalnie występująca lowastatyna - monakolina $\mathrm{K}$ - obecna jest w czerwonym ryżu drożdżowym

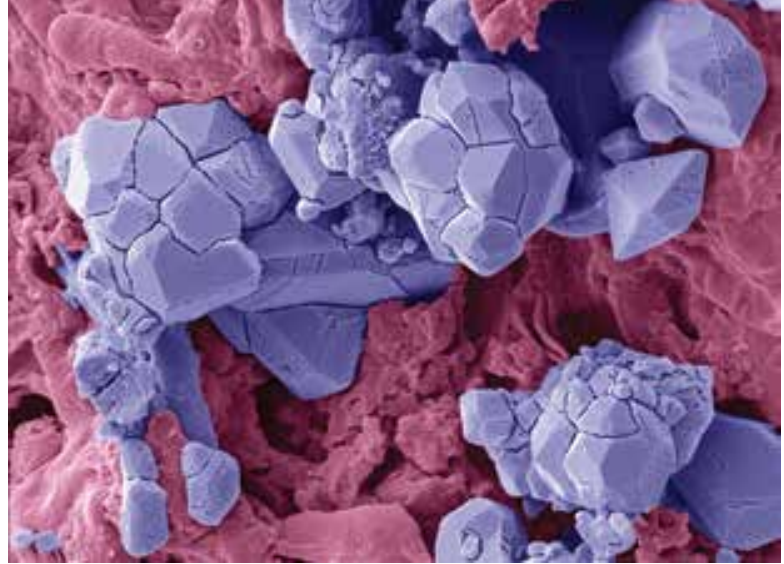

Rycina 3. Obraz mikroskopowy czerwonego ryżu drożdżowego (za zgodą z: http://www.gettyimages.com/license/128625251)

(RYR, red yeast rice) będącym istotnym elementem tradycyjnej kuchni wschodniej, wykorzystywanym jako barwnik lub przyprawa (ryc. 3). Monakolina powstaje w procesie fermentacji grzyba Monascus purpureus na ziarnach wypolerowanego ryżu.

\section{Monakolina - od starożytności do współczesności}

Zastosowanie czerwonego ryżu drożdżowego w Chinach zostało po raz pierwszy udokumentowane podczas panowania dynastii Tang w 800 roku. Czerwony ryż drożdżowy używany był do produkcji wina, jako substancja konserwująca pokarmy oraz nadająca charakterystyczny kolor oraz walory smakowe rybom i potrawom mięsnym, miał również 
zastosowanie medyczne [13]. Szczegółowy opis RYR zawiera historyczna chińska farmakopea pochodząca z dynastii Ming (1368-1644) [14]. Tekst ten opisuje zastosowanie RYR jako środka korzystnie wpływającego na układ krążenia. W badaniach przeprowadzonych w populacji chińskiej oraz w badaniach z użyciem modeli zwierzęcych RYR powodował redukcję stężenia cholesterolu o 11-32\%, a TG o 12-19\% [15-19]. Czerwony ryż drożdżowy wciąż stanowi ważny element codziennej diety w krajach azjatyckich, takich jak Chiny i Japonia. Dzienne spożycie RYR w tych krajach wynosi 14-55 g/osobę/dzień [20].

\section{Działanie hipolipemizujące czerwonego ryżu} drożdżowego w badaniach i obserwacjach

Działanie hipolipemizujące RYR było przedmiotem licznych obserwacji i analiz. Heber i wsp. przeprowadzili prospektywne, kontrolowane placebo badanie obejmujące 83 nieleczonych pacjentów z hipercholesterolemią [21]. U chorych stosowano preparat RYR w dawce 2,4 g przez 12 tygodni. W grupie przyjmującej RYR stężenie cholesterolu całkowitego wynosiło $208 \pm 31 \mathrm{mg} / \mathrm{dl}$, a w grupie otrzymującej placebo $-254 \pm 36 \mathrm{mg} / \mathrm{dl}$ po 8 tygodniach stosowania RYR ( $p<0,001)$. W grupie stosującej czerwony fermentowany ryż obserwowano istotną redukcję stężenia TC w 12. tygodniu badania wynoszącą $40 \pm 21 \mathrm{mg} / \mathrm{dl}$. W grupie przyjmującej placebo spadek ten wynosił $5 \pm 20 \mathrm{mg} / \mathrm{dl}$. Istotna różnica między grupą stosującą RYR i placebo występowała również w stężeniu LDL-C. Po 12 tygodniach w grupie badanej stężenie LDL-C wynosiło $135 \pm 27 \mathrm{mg} / \mathrm{dl}$, w grupie kontrolnej $175 \pm 33 \mathrm{mg} / \mathrm{dl}(\mathrm{p}<0,001)$. Zmniejszenie wartości LDL w surowicy obserwowano u wszystkich, oprócz jednego, pacjentów stosujących RYR i wynosiło $39 \pm 19 \mathrm{mg} / \mathrm{dl}$, natomiast w grupie przyjmującej placebo $5 \pm 22 \mathrm{mg} / \mathrm{dl}$. Redukcja stężenia TG była istotna statystycznie po 8 tygodniach $(p=0,05)$, ale już nie po 12 tygodniach. Nie obserwowano natomiast istotnych różnic w stężeniu HDL-C między grupami.

Skuteczność działania hipolipemizującego monakoliny K zawartej w czerwonym ryżu drożdżowym była również oceniona przez Lin i wsp. w randomizowanym badaniu przeprowadzonym metodą podwójnie ślepej próby [22]. Do badania włączono 79 pacjentów w wieku 23-65 lat. Stężenie LDL w momencie rozpoczęcia badania wynosiło 203,9 mg/dl. Chorzy otrzymywali preparat RYR w dawce $600 \mathrm{mg}$ (zawierający 5,7 mg monakoliny K) 2 razy dziennie. Po 8 tygodniach stwierdzono istotną redukcję stężenia LDL-C w grupie badanej o 27,7\%, TC o 21,5\%, TG o 15,8\%, apoB o 26\%. Jednocześnie stwierdzono nieistotny statystycznie wzrost stężenia HDL-C (o 0,9\%) oraz apolipoproteriny A - o 3,4\%. Zwraca uwage również fakt, że stosowane postępowanie nie wiązało się z wystąpieniem działań niepożądanych zdefiniowanych w badaniu jako wzrost aktywności aminotransferaz oraz kinazy kreatynowej (CPK, creatine phosphokinase) większy lub równy 3-krotności górnej granica normy, ocenianych po 4 tygodniach i na koniec badania.

Gerards i wsp. dokonali oceny skuteczności oraz bezpieczeństwa stosowania preparatów RYR, przeprowadzając metaanalizę 20 randomizowanych badań klinicznych obejmujących 6663 pacjentów [23]. Dawka RYR stosowana w poszczególnych badaniach wynosiła 1200-4800 mg/ /dobę, co odpowiadało 4,8-24 mg monakoliny K. W badaniach kontrolowanych placebo średnia redukcja stężenia cholesterolu wynosiła 39,4 mg/dl (1,02 mmol/l), redukcja stężenia TG wyniosła $23 \mathrm{mg} / \mathrm{dl}(0,26 \mathrm{mmol} / \mathrm{l})$, zanotowano również niewielki wzrost stężenia HDL-C o $2,7 \mathrm{mg} / \mathrm{dl}$ (0,07 mmol/I). W trzech z ocenianych badań porównywano zastosowanie dawki $10 \mathrm{mg}$ monakoliny $\mathrm{K}$ z terapią statyną (prawastatyna $4 \mathrm{mg}$, simwastatyna $10 \mathrm{mg}$, lowastatyna $20 \mathrm{mg}$ - nie stwierdzono istotnych różnic dotyczących działania hipolipemizującego porównywanych preparatów.

Kolejnej metaanalizy podjęli się Liu i wsp., oceniając 93 randomizowane badania obejmujących ponad 9 tys. pacjentów [24]. Dowiedziono, że stosowanie preparatów zawierających monakolinę $\mathrm{K}$ wiązało się ze zmniejszeniem stężenia LDL-C o 28,2 mg/dl (0,73 mmol/l), TC o 35,2 mg/dl $(0,91 \mathrm{mmol} / \mathrm{l}), \mathrm{TG}$ o $36,3 \mathrm{mg} / \mathrm{dl}(0,41 \mathrm{mmol} / \mathrm{l})$, a także ze zwiększeniem stężenia HDL-C średnio o $5,8 \mathrm{mg} / \mathrm{dl}$ $(0,15 \mathrm{mmol} / \mathrm{I}) \mathrm{w}$ porównaniu z grupą otrzymującą placebo. Według autorów metaanalizy wpływ preparatów zawierających monakolinę $\mathrm{K}$ na redukcję stężenia lipidów w surowicy był porównywalny do ekwipotencjalnych dawek simwastatyny, atorwastatyny, prawastatyny, fluwastatyny. Skuteczność analizowanych preparatów monakoliny $\mathrm{K}$ była większa od kwasu nikotynowego i produktów zawierających oleje rybie [24].

Działanie preparatów czerwonego ryżu drożdżowego oceniano również $w$ populacji chorych po przebytym zawale serca [25]. Lu i wsp. przeprowadzili randomizowane, kontrolowane placebo badanie prowadzone metoda podwójnie ślepej próby w populacji chińskiej obejmującej 3986 mężczyzn oraz 884 kobiety. Chorzy otrzymywali preparat czerwonego ryżu drożdżowego Xuezhikang (XZK) w dawce $300 \mathrm{mg}$, będący odpowiednikiem 2,5-3,2 mg lowastatyny, 2 razy/dobę. Obserwacja trwała ponad 4,5 roku. Głównym punktem końcowym było wystąpienie incydentu wieńcowego, w tym zawału serca niezakończonego zgonem oraz zgonu z przyczyn sercowo-naczyniowych. U chorych stosujących XZK obserwowano istotnie mniejszą częstość występowania zawałów serca oraz zgonów sercowo-naczyniowych w porównaniu z grupą otrzymująca placebo odpowiednio o $10,4 \%$ oraz $5,7 \%$ ( $p<0,001)$. U chorych przyjmujących XZK obserwowano również zmniejszenie odsetka ponownych rewaskularyzacji o 33\% w stosunku do grupy stosującej placebo $(p=0,004)$. W badanej grupie po 8 tygodniach leczenia redukcja stężenia TC wynosiła 10,9\% ( $p<0,001)$, a LDL-C 17,6\% ( $p<0,001)$. Efekt ten utrzymywał się przez cały okres trwania obserwacji. 
Moriarty i wsp. przeprowadzili wieloośrodkowe badanie oceniające skuteczność hipolipemizującą XZK [26]. Badanie zostało przeprowadzone w 15 ośrodkach w Chinach oraz Stanach Zjednoczonych i obejmowało 116 pacjentów z dyslipidemią. Chorzy otrzymywali preparat zawierający XZK (monakolinę K) w dawce 12 mg lub 2 mg przez 4-12 tygodni. Grupa kontrolna otrzymywała placebo. Stosowanie XZK było dobrze tolerowane i wiązało się ze zmniejszeniem stężenia nie-HDL-C o 24\% ( $p<0,001$ ), a LDL-C o 27\% ( $p<0,001$ ) w stosunku do grupy przyjmującej placebo. Podwojenie dawki w 8. tygodniu badania wiązało się z dodatkową redukcją stężenia LDL-C o 4,6\%. U prawie połowy pacjentów otrzymujących XZK osiągnięto zmniejszenie stężenia LDL-C o 30\% w stosunku do wartości wyjściowej.

Przeprowadzono również badania z zastosowaniem monakoliny $\mathrm{K}$ u chorych ze wskazaniami do leczenia hipolipemizującego, u których uprzednio z powodu działań niepożądanych terapia statynami została przerwana. Halbert i wsp. ocenili skuteczność oraz bezpieczeństwo stosowania monakoliny w niewielkiej, liczącej 43 osoby grupie chorych z hipercholesterolemią [27]. Prowadzone wcześniej leczenie hipolipemizujące z zastosowaniem statyny wiązało się z występowaniem mialgii. Chorzy zostali losowo przydzieleni do dwóch grup, z których w jednej leczenie hipolipemizujące prowadzone było z zastosowaniem $20 \mathrm{mg}$ prawastatyny, z kolei w drugiej grupie chorzy otrzymywali $2400 \mathrm{mg}$ preparatu zawierającego czerwony ryż drożdżowy. Obie substancje były przyjmowane 2 razy/dobę. Efekty postępowania oceniono po 12 tygodniach. W grupie, w której stosowano monakolinę, obserwowano redukcję stężenia LDL-C o 30\%, a u chorych leczonych prawastatyną o 27\%. Częstość nawrotów dolegliwości bólowych ze strony mięśni była niewielka, zbliżona w grupie stosującej RYR i prawastatynę, wynosząc odpowiednio 5\% oraz 9\% [27].

Becker i wsp. poddali ocenie skuteczność monakoliny u chorych, u których obserwowano działania niepożądane w trakcie leczenia statynami [28]. Do badania włączono 62 chorych z hipercholesterolemią. Średnie stężenie LDL-C w badanej grupie wynosiło 163,3 mg/dl. Chorych przydzielono losowo do grupy stosującej preparat RYR lub do grupy otrzymującej placebo. Po 12 tygodniach leczenia stwierdzono, że stosowanie preparatu RYR wiązało się ze zmniejszeniem stężenia LDL-C o 27,3\%, a efekt terapeutyczny utrzymywał się przez kolejne 24 tygodnie obserwacji. U osób przyjmujących preparat zawierający monakolinę nie stwierdzono dolegliwości bólowych ze strony mięśni. Nie obserwowano również wzrostu aktywności CPK ani aminotransferaz w surowicy krwi w trakcie leczenia. Utrzymująca się mialgia występowała u 7\% pacjentów w grupie otrzymującej RYR oraz 3\% w grupie przyjmującej placebo. Występujące dolegliwości bólowe nie wiązały się jednak ze wzrostem aktywności CPK. Zwraca uwagę fakt, że RYR stosowany w tym badaniu charakteryzował się niewielką zawartością monakoliny $\mathrm{K}$ (jedynie 1,02 mg/600 mg produktu) odpowiadającą dziennej dawce lowastatyny wynoszącej $6 \mathrm{mg}$. Autorzy zwrócili uwagę, że możliwe, że zastosowano zbyt małą dawkę, by mogła ona spowodować wystąpienie objawów [28].

Wyniki przeprowadzonych dotychczas badań potwierdzają wysoki profil bezpieczeństwa monakoliny, działania niepożądane zwykle mają charakter łagodny i pojawiają się z podobną częstotliwością co w grupach placebo, ale znane są również opisy przypadków ilustrujące możliwość wystąpienia miopatii [29]. Trzeba również pamiętać, że monakolina K może zwiększać ryzyko powikłań leczenia statynami, w tym nasilać częstość występowania miopatii. Nie należy zatem stosować statyny i monakoliny $\mathrm{K}$ w skojarzeniu w leczeniu dyslipidemii. Naturalne pochodzenie monakoliny jest jej niewątpliwą zaletą, utrudnieniem natomiast jest brak możliwości standaryzacji dawki w warunkach spożywania monakoliny w produkcie spożywczym, to jest w postaci czerwonego ryżu drożdżowego. Zawartość monakoliny $\mathrm{K}$ może być istotnie różna w potrawach przygotowywanych według odmiennych receptur.

\section{Dla kogo i kiedy monakolina?}

Przytoczone dane pochodzące z randomizowanych badań klinicznych potwierdzają skuteczność stosowania monakoliny $\mathrm{K}$ w celu redukcji stężenia cholesterolu we krwi. Opinia zawarta w oświadczeniu Europejskiego Urzędu do spraw Bezpieczeństwa Żywności (EFSA, European Food Safety Authority) dotyczącym monakoliny K w sfermentowanym czerwonym ryżu potwierdza, że wykazano związek przyczynowo-skutkowy między spożywaniem monakoliny $\mathrm{K}$ w preparatach ze sfermentowanego czerwonego ryżu a utrzymaniem prawidłowego stężenia LDL-C we krwi. Wspomniany dokument zaleca, by w celu uzyskania deklarowanego działania osoby dorosłe z populacji ogólnej spożywały dziennie $10 \mathrm{mg}$ monakoliny $\mathrm{K}$ pochodzącej z preparatów ze sfermentowanego czerwonego ryżu [30]. Zastosowanie suplementów diety zawierających czerwony ryż drożdżowy jako element prozdrowotnej modyfikacji stylu życia mającej korzystny wpływ na stężenie lipidów jest zalecane przez europejskie wytyczne postępowania w dyslipidemiach [4].

Dostępne dane naukowe potwierdzają działanie hipolipemizujące monakoliny $\mathrm{K}$ pozwalające na redukcję stężenia LDL-C o 10-20\% w stosunku do wartości wyjściowej w przypadku stosowania dawki $10 \mathrm{mg}$, a nawet ponad 30\% dla dawki $80 \mathrm{mg}$ [31].

Docelową grupę osób, w której można rozważyć zastosowanie monakoliny, stanowią pacjenci z grupy niskiego ( $<1 \%$ w skali SCORE) lub umiarkowanego (1-5\% w skali SCORE) ryzyka sercowo-naczyniowego (tab. 1, 2) [8]. Zastosowanie monakoliny można ewentualnie rozważyć w grupie chorych dużego ryzyka sercowo-naczyniowego, u których wyjściowo stężenie LDL-C nie przekracza 100 mg/dl, zwłaszcza gdy chorzy z różnych względów nie mogą bądź odmawiają ini- 
Tabela 1. Strategie leczenia hipolipemizującego zależnie od całkowitego ryzyka choroby układu sercowo-naczyniowego (CVD, cardiovascular diseases) i stężenia cholesterolu frakcji lipoprotein o niskiej gęstości (LDL, low-density lipoprotein) (źródło [4])

\begin{tabular}{|c|c|c|c|c|c|}
\hline \multirow{2}{*}{$\begin{array}{l}\text { Całkowite ryzyko } \\
\text { CVD (\%) }\end{array}$} & \multicolumn{5}{|c|}{ Stężenie LDL-C [mg/dl] ([mmol/l] $)$} \\
\hline & $\begin{array}{l}<70 \\
(<1,8)\end{array}$ & $\begin{array}{l}70 \text { do }<100 \\
(1,8 \text { do }<2,5)\end{array}$ & $\begin{array}{l}100 \text { do }<155 \\
(2,5 \text { do }<4,0)\end{array}$ & $\begin{array}{l}155 \text { do }<190 \\
(4,0 \text { do }<4,9)\end{array}$ & $\begin{array}{l}>190 \\
(>4,9)\end{array}$ \\
\hline$<1$ & Bez interwencji & Bez interwencji & $\begin{array}{l}\text { Modyfikacja stylu } \\
\text { życia }\end{array}$ & $\begin{array}{l}\text { Modyfikacja stylu } \\
\text { życia }\end{array}$ & $\begin{array}{l}\text { Modyfikacja stylu życia, } \\
\text { rozważyć leki przy braku } \\
\text { kontroli }\end{array}$ \\
\hline Klasa/poziom & $\mathrm{I} / \mathrm{C}$ & I/C & $\mathrm{I} / \mathrm{C}$ & $\mathrm{I} / \mathrm{C}$ & Ila/A \\
\hline $0 d \geq 1$ do $<5$ & $\begin{array}{l}\text { Modyfikacja } \\
\text { stylu życia }\end{array}$ & $\begin{array}{l}\text { Modyfikacja stylu } \\
\text { życia }\end{array}$ & $\begin{array}{l}\text { Modyfikacja stylu } \\
\text { życia, rozważyć leki } \\
\text { przy braku kontroli }\end{array}$ & $\begin{array}{l}\text { Modyfikacja stylu } \\
\text { życia, rozważyć leki } \\
\text { przy braku kontroli }\end{array}$ & $\begin{array}{l}\text { Modyfikacja stylu życia, } \\
\text { rozważyć leki przy braku } \\
\text { kontroli }\end{array}$ \\
\hline Klasa/Poziom & $\mathrm{l} / \mathrm{C}$ & $\mathrm{l} / \mathrm{C}$ & Ila/A & Ila/A & $\mathrm{I} / \mathrm{A}$ \\
\hline $\begin{array}{l}O d \geq 5 \text { do }< \\
10 \text { lub wysokie } \\
\text { ryzyko }\end{array}$ & $\begin{array}{l}\text { Modyfikacja } \\
\text { stylu życia, roz- } \\
\text { ważyć leczenie } \\
\end{array}$ & $\begin{array}{l}\text { Modyfikacja stylu } \\
\text { życia, rozważyć } \\
\text { leczenie }\end{array}$ & $\begin{array}{l}\text { Modyfikacja stylu } \\
\text { życia i natychmia- } \\
\text { stowe leczenie }\end{array}$ & $\begin{array}{l}\text { Modyfikacja stylu } \\
\text { życia i natychmia- } \\
\text { stowe leczenie }\end{array}$ & $\begin{array}{l}\text { Modyfikacja stylu życia } \\
\text { i natychmiastowe le- } \\
\text { czenie }\end{array}$ \\
\hline Klasa/Poziom & $\mathrm{I} / \mathrm{C}$ & $\mathrm{l} / \mathrm{C}$ & Ila/A & Ila/A & $\mathrm{I} / \mathrm{A}$ \\
\hline $\begin{array}{l}\geq 10 \text { lub bardzo } \\
\text { wysokie ryzyko }\end{array}$ & $\begin{array}{l}\text { Modyfikacja } \\
\text { stylu życia, roz- } \\
\text { ważyć leczenie }\end{array}$ & $\begin{array}{l}\text { Modyfikacja stylu } \\
\text { życia i natychmia- } \\
\text { stowe leczenie }\end{array}$ & $\begin{array}{l}\text { Modyfikacja stylu } \\
\text { życia i natychmia- } \\
\text { stowe leczenie }\end{array}$ & $\begin{array}{l}\text { Modyfikacja stylu } \\
\text { życia i natychmia- } \\
\text { stowe leczenie }\end{array}$ & $\begin{array}{l}\text { Modyfikacja stylu życia } \\
\text { i natychmiastowe le- } \\
\text { czenie }\end{array}$ \\
\hline Klasa/Poziom & $\mathrm{Ila} / \mathrm{A}$ & Ila/A & I/A & I/A & I/A \\
\hline
\end{tabular}

Tabela 2. Miejsce monakoliny w terapii dyslipidemii (obok diety i żywności funkcjonalnej jako możliwej pierwszej interwencji - kolor czerwony, ew. alternatywnej interwencji, np. w przypadku nietolerancji statyn - kolor jasnoczerwony) (modyfikacja autorów na podstawie [4])

\begin{tabular}{|c|c|c|c|c|c|}
\hline \multirow[t]{2}{*}{ Całkowite ryzyko CVD (\%) } & \multicolumn{5}{|c|}{ Stężenie LDL-C [mg/dl] ([mmol/l] $)$} \\
\hline & $\begin{array}{l}<70 \\
(<1,8)\end{array}$ & $\begin{array}{l}70 \text { do }<100 \\
(1,8 \text { do }<2,5)\end{array}$ & $\begin{array}{l}100 \text { do }<155 \\
(2,5 \text { do }<4,0)\end{array}$ & $\begin{array}{l}155 \text { do }<190 \\
(4,0 \text { do }<4,9)\end{array}$ & $\begin{array}{l}>190 \\
(>4,9)\end{array}$ \\
\hline$<1$ & Bez interwencji & Bez interwencji & Monakolina & Monakolina & Monakolina \\
\hline Klasa/poziom & I/C & $\mathrm{l} / \mathrm{C}$ & $\mathrm{I} / \mathrm{C}$ & $\mathrm{l} / \mathrm{C}$ & Ila/A \\
\hline $0 d \geq 1$ do $<5$ & Monakolina & Monakolina & Monakolina & Monakolina & Monakolina \\
\hline Klasa/poziom & I/C & $\mathrm{l} / \mathrm{C}$ & Ila/A & Ila/A & I/A \\
\hline Od $\geq 5$ do $<10$ lub wysokie ryzyko & Monakolina & Monakolina & Statyna & Statyna & Statyna \\
\hline Klasa/poziom & $\mathrm{I} / \mathrm{C}$ & $\mathrm{l} / \mathrm{C}$ & Ila/A & $\mathrm{Ila} / \mathrm{A}$ & I/A \\
\hline$\geq 10$ lub bardzo wysokie ryzyko & Statyna & Statyna & Statyna & Statyna & Statyna \\
\hline Klasa/poziom & $\mathrm{Ila} / \mathrm{A}$ & $\mathrm{Ila} / \mathrm{A}$ & I/A & I/A & I/A \\
\hline
\end{tabular}

CVD (cardiovascular diseases) - choroba układu sercowo-naczyniowego; LDL-C (low-density lipoprotein cholesterol) - cholesterol frakcji lipoprotein o niskiej gęstości

cjowania terapii statyną. Badania Halberta i wsp. dowodzą, że chorzy z mialgią postatynową dobrze tolerują leczenie monakoliną K [27]. Pamiętać jednak należy, że terapia monakoliną może być uzupełnieniem, a nie alternatywą dla terapii behawioralnej, zaś w przypadku chorych dużego i bardzo dużego ryzyka podstawą terapii hipolipemizującej pozostają statyny.

Powyższe stanowisko wyrażają autorzy Deklaracji Sopockiej II, którzy zalecają bez względu na rodzaj stosowanej terapii hipolipemizującej modyfikację stylu życia. Może być ona jedyną, a w każdej sytuacji podstawową interwencją, uzupełnianą kolejnymi działaniami terapeutycznymi. Zastosowanie żywności funkcjonalnej może prowadzić dodatkowo do redukcji stężenia LDL-C o 10\%, a przy użyciu monakoliny o 20\%. Podstawę piramidy modyfikacji lipidogramu i interwencji leczniczych stanowi modyfikacja stylu życia, a wierzchołek intensywna terapia silnymi statynami i terapia skojarzona [2]. 


\section{Abstract}

Cardiovascular diseases (CVD) are the main cause of the premature death in the world. Dyslipidemia is the most common CVD risk factor that may be modified. Main intervention leading to the normalization of cholesterol level is lifestyle modification i.e. proper diet and physical activity. Statins are the most important group of drugs used in cholesterol lowering therapy. Use of functional food or dietary supplements - like monacolin $\mathrm{K}$, may be a step between mentioned above therapies. Effectiveness of monacolin $\mathrm{K}$ in lowering of cholesterol level has been proved in various randomized clinical trials. Use of dietary supplements or functional food may be appropriate in patients with low or moderate cardiovascular risk and patients with high cardiovascular risk but LDL-cholesterol lower than $100 \mathrm{mg} / \mathrm{dl}$.

Key words: dyslipidemia, cardiovascular risk, statins

Folia Cardiologica 2016; 11, 4: 318-326

\section{Piśmiennictwo}

1. Nichols M., Townsend N., Luengo-Fernandez R. i wsp. European Cardiovascular Disease Statistics 2012. European Heart Network, Bruksela 2012.

2. Wożakowska-Kapłon B., Filipiak K.J., Mamcarz A. i wsp. Aktualne problemy terapii dyslipidemii w Polsce - II Deklaracja Sopocka. Stanowisko grupy ekspertów wsparte przez Sekcję Farmakoterapii Sercowo-Naczyniowej Polskiego Towarzystwa Kardiologicznego. Kardiol. Pol. 2014; 72: 847-853.

3. Zdrojewski T., Solnica B., Cybulska B. i wsp. Prevalence of lipid abnormalities in Poland. The NATPOL 2011 survey. Kardiol. Pol. 2016; 74: 213-223.

4. Reiner Ž., Catapano A.L., De Backer G. i wsp. ESC/EAS Guidelines for management of dyslipidaemias of the European Society of Cardiology (ESC) and the European Atherosclerosis Society (EAS). Eur. Heart J. 2011; 32: 1769-1818.

5. Cholesterol Treatment Trialists' (CTT) Collaboration. Efficacy and safety of more intensive lowering of LDL cholesterol: a meta-analysis of data from 170000 participants in 26 randomised trials. Lancet 2010; 376: 1670-1681.

6. Brugts J.J., Yetgin T., Hoeks S.E. i wsp. The benefits of statins in people without established cardiovascular disease but with cardiovascular risk factors: meta-analysis of randomised controlled trials. BMJ 2009; 338: b2376.

7. Mills E.J., Rachlis B., Wu P. i wsp. Primary prevention of cardiovascular mortality and events with statin treatments. A network meta-analysis involving more than 65,000 patients. J. Am. Coll. Cardiol. 2008; 52: 1769-1781.

8. Piepoli M.F., Hoes A.W., Agewall S. i wsp.; Authors/Task Force Members. 2016 European Guidelines on cardiovascular disease prevention in clinical practice: the Sixth Joint Task Force of the European Society of Cardiology and Other Societies on Cardiovascular Disease Prevention in Clinical Practice (constituted by representatives of 10 societies and by invited experts) Developed with the special contribution of the European Association for Cardiovascular Prevention \& Rehabilitation (EACPR). Eur. Heart J. 2016; 37: 2315-2381.

9. Nowak A. Fitosterole w codziennej diecie. Post. Fitoter. 2011; 1: 48-51.

10. Endo $A$. The discovery and development of HMG-CoA reductase inhibitors. J. Lipid. Res. 1992; 33: 1569-1582.

11. Endo A. The origin of the statins. Atheroscler. Suppl. 2004; 5: 125-130.
12. Williams O., Jacks A.M., Davis J. i wsp. Case 10: Merck (A): Mevacor. W: Afuah A. (red.). Innovation management - strategies, implementation and profits. Oxford University Press, Oxford 1998.

13. Stuart M.D. Chinese materia medica - vegetable kingdom. Southern Materials Center Inc., Taipei 1979.

14. Yingxing S. T'ien Jung K'ai Wu. Chinese technology in the seventeenth century. Pennsylvania State University Press, University Park and London 1966: 291-294.

15. Zhu Y., Li C.L., Wang Y.Y. Effects of Xuezhikang on blood lipids and lipoprotein concentrations of rabbits and quails with hyperlipidemia. Chin. J. Pharmacol. 1995; 30: 4-8.

16. Li C.L., Li Y.F., Hou Z.L. Xuezhikang toxicity study. Bull. Chinese Pharmacol. Soc. 1995; $12: 3$.

17. Zhu Y., Li C.L., Wang Y.Y. i wsp. Monascus purpureus (red yeast): a natural product that lowers blood cholesterol in animal models of hypercholesterolemia. Nutr. Res. 1998; 18: 71-81.

18. Wang J., Su M., Lu Z. i wsp. Clinical trial of extract of Monascus purpureus (red yeast) in the treatment of hyperlipidemia. Chin. J. Exp. Ther. Prep. Chin. Med. 1995; 12: 1-5.

19. Shen Z., Yu P., Su M. i wsp. A prospective study on Zhitai capsule in the treatment of primary hyperlipidemia. Nat. Med. J. China 1996; 76: 156-157.

20. Mei F. Red yeast flavored duck. W: Fang Mei's illustrated cookbook of regional Chinese cuisine. Guangxi National Press, Guangxi 1990: 177-188.

21. Heber D., Yip I., Ashley J.M. i wsp. Cholesterol-lowering effects of a proprietary Chinese red-yeast-rice dietary supplement. Am. J. Clin. Nutr. 1999; 69: 231-236.

22. Lin C.C., Li T.C., Lai M.M. Efficacy and safety of Monascus purpureus Went rice in subjects with hyperlipidemia. Eur. J. Endocrinol. 2005; 153: 679-686.

23. Gerards M.C., Terlou R.J., Yu H. i wsp. Traditional Chinese lipid-lowering agent red yeast rice results in significant LDL reduction but safety is uncertain - a systemic review and meta-analysis. Atherosclerosis 2015; 240: 415-423.

24. Liu J., Zhang J., Shi Y. i wsp. Chinese red yeast rice (Monascus purpureus) for primary hyperlipidemia: a meta-analysis of randomized controlled trails. Chines. Med. 2006; 1: 1-4.

25. Lu Z., Kou W., Du B. i wsp. Effect of Xuezhikang, an extract from red yeast Chinese rice, on coronary events in a Chinese population with previous myocardial infarction. Am. J. Cardiol. 2008; 101: 1689-1693. 
26. Moriarty P.M., Roth E.M., Karns A. i wsp. Effects of Xuezhikang in patients with dyslipidemia: a multicenter, randomized, placebo-controlled study J. Clin. Lipidol. 2014; 8: 568-575.

27. Halbert S.C., French B., Gordon R.Y. i wsp. Tolerability of red yeast rice ( $2400 \mathrm{mg}$ twice daily) versus pravastatin ( $20 \mathrm{mg}$ twice daily) in patients with previous statin intolerance. Am. J. Cardiol. 2010; 105: 198-204.

28. Becker D.J., Gordon H.Y., Halbert S.C. i wsp. Red yeast rice for dyslipidemistatin-intolerant patients, a randomized trial. Ann. Intern. Med. 2009; 150: 830-839.
29. Mueller P.S. Symptomatic myopathy due to red yeast rice. Ann. Intern. Med. 2006; 145: 474-475.

30. EFSA Panel on Dietetic Products, Nutrition and Allergies (NDA). Scientific Opinion on the substantiation of health claims related to monacolin $\mathrm{K}$ from red yeast rice and maintenance of normal blood LDL-cholesterol concentrations (ID 1648, 1700) pursuant to Article 13(1) of Regulation (EC) No 1924/2006. EFSA J. 2011; 9: 2304.

31. Sobień B., Kopeć G., Podolec P. Statyny. Podręcznik Polskiego Forum Profilaktyki. Tom 2. Medycyna Praktyczna, Kraków 2010: 659-666. 